\title{
Islamic Law and Social Change: How does Islam take a Stand?
}

\section{$\underline{\text { Tolkah }}$}

Sekolah Tinggi Ilmu Hukum Gunung Djati, Indonesia

Email: dr.tolkah@gmail.com

\begin{abstract}
:
Social change in Muslim is usually marked by the development of the Muslim civilization, social change has been absorbed through the interaction between religion and society which has implications for social processes. Social change in society always demands changes in Islamic law. Sociologically, society is always changing. Literature study research method with a qualitative approach. The conclusion from this literature research can be concluded that the relationship between Islamic law and social change is reciprocal and influences each other, Islam takes a stand to be able to keep up with the times in its own way.
\end{abstract}

\section{Keywords:}

Islamic law; social change; Muslim

\section{Introduction}

The emergence of issues within a group or organization is unpredictable. Issues arise when a problem becomes focused on a specific point that can lead to debate. So that it requires handling, otherwise it will have a negative influence in the group or organization (Alfin, 2017). The meaning of the issue here leads to a problem in a group, organization, institution, which desperately needs a solution (Ridla, 2014).

In fact, in the life of Muslims at the time of the Prophet, the problems faced by Muslims were still very simple, such as differences in the Arabian Peninsula, traditions, patterns, social life, and economic levels are not much different, even though at this time Islam has been embraced by the community (Wagianto, 2017). However, with the development of the times, the progress of Islamic law is faced with the complexity of social problems that continue to change according to changes in time and place (Hamdi, 2018). Social change that demands adaptability because change is a necessity. It has become a necessity that a society always experiences changes which are often followed by changes in mindset and values (Soekanto, 2007).

Basically, Islamic law is known as transcendental law which has its own validity and is completely different from man-made law (Rokhmad, 2017). Islamic law is a rule that regulates the behavior of Muslim life to make it more orderly. Because in simple terms Islamic law is stated by the metata law of all life in Islam (Zayyadi, 2020). As stated by MacDonald that Islamic law is the science of all things human and divine (MacDonald, 1903). With this, the importance of Islamic law in the development of Islam in Indonesia. The achievement of the essence of Islamic law as a bulwark against this change certainly requires a long study. This paper tries to study and explore the application of Islamic law in the midst of social change in Indonesia 


\section{Research Methods}

Judging from the title and problems studied, this research is a type of library research with a qualitative approach (Muslim, 2017), which is research that does not compute quantitative data. The main or primary literature studied in this research is Islamic law books and literature. As a library research, the data collection method used is the documentation method, namely data on variables in the form of books, notes, transcripts, journals, and so on.

While the data analysis technique chosen is descriptive analysis using a series of logical thinking systems that can be used to construct a number of concepts into propositions, hypotheses, postulates, axioms, assumptions, or to construct a theory (Arikunto, 2010). These systems of thought are (a) perceptive systems of thought, which are used to perceive data that is appropriate and relevant to the issues under study; (b) descriptive thought system, which is used to describe the data systematically in accordance with the systematic discussion used in this study.

\section{Results and Discussion}

\subsection{Islamic Law}

Hasbi As-Shiddieqy (1990) provides a definition of Islamic law as a collection of the efforts of legal experts to establish sharia based on the needs of society. The definition given by Hasbi is closer to al-fiqh, not to shari'at (Hilal, 2003). Sharia is Islamic law that applies throughout the ages, while figh is a concrete formulation of Islamic law to be applied in a particular case, in a certain place, situation and period (Adi, 2012).

The two are distinguishable but inseparable. This is stated as an effort to reconfirm the meaning of Islamic law itself, so that there is no confusion in seeing Islamic law, either as a teaching or as a result of interpretation, interpretation, and thoughts of the mujtahids (Wello, 2010). According to Islamic law, Punishment is a reward for the perpetrators of organized crime by Personality 'which are generally aimed at the welfare of the community (Munawarsyah et al, 2018).

Islam as a religion that brings mercy to all nature has teachings and rules of law which are always oriented to the benefit of humans. Every law that is prescribed must contain the value of benefits returned to humans, it's just that the value of benefits is sometimes not found after reasoning. But generally, in the applied laws can be found the value of benefits which is also called the wisdom of the law or the philosophical basis of law (Helmi et al, 2019).

Principal legal provisions are permanent and final, do not accept or deny renewals and changes. The provisions of Islamic law have been explained and stipulated by the Koran and Sunnah in a definite, clear and detailed manner (Adibah, 2017). In addition, there are also legal provisions that are not fixed or final, and can change, legal provisions like this can be divided into two types, namely: first, laws which are extracted from zhanni arguments but change dynamically. Second, the law produced through ijtihad as a result and response to the development of the times (Mahendra, 2007). In the theory of Ushul fiqih, ijtihad can only be done in certain areas, namely: a) the arguments that are qath'i al-wurudh but zhanni dalalah; b) arguments that are zhanni al-wurudh but qath'i al-dalalah; c) arguments that are zhanni alwurud and dalalah; d) for cases where there is no legal argument (Djazuli, 2005). 
From the above explanation, it shows that the two sources of law, namely the Koran and the Sunnah, have texts that are partly qath'i (axiomatic) and partly zhanni (hypothetical). In texts that are zhanni human reason makes it possible to interpret interpretations and adjust meaning to the demands of these social changes (Zuhri, 2014). Even not only zhanni texts, qath'i texts can also undergo changes, this is where the flexibility of Islamic law lies. Islamic law is also fair in relation to this overarching nature for individuals and society.

\subsection{Social Transformation}

The occurrence of social change in society is inevitable. The changes in society that occur can be in the form of a social order, a cultural order, an economic order and so on. Change occurs not only partially, in certain aspects but is comprehensive. Meanwhile, social changes have a positive and negative impact on society. One of the ways to minimize the negative impact of existing changes is the importance of religious teachings as an ideological foundation in fortifying negative changes. Whether they are aware of it or not, religious teachings have a profound spiritual influence on adherents.

Adapu the notion of social change according to Wilbert Moore as quoted by Robert H. Lauer that social change is an important change of the social structure, the social structure referred to here is the patterns of behavior and interactions. Moore has included in the definition of social change various expressions of structure such as cultural norms, values, and phenomena. This definition shows that social change is a complex phenomenon, penetrates various levels of social life, and indicates that all social aspects of society undergo continuous change. Even if there are differences, they only differ in the level of change (Robert, 2003). According to Abdulsyani, gilin and gilin have argued that social change is a variation of an acceptable and applicable way of life. These changes can occur either because they are triggered by changes in geographical conditions, population composition, culture, ideology, and diffusion or new discoveries in society (Abdulsyani, 2007).

Based on the above opinion, it can be concluded that social change refers to changes in social order, changes in people's way of life, both changes in values, changes in social behavior, and social relations caused by changes in geographical, ideological and cultural conditions. In addition, there are other causes of social change, namely due to the development of science and technology. This is marked by the existence of modern communication using rapidly developing technology. The rules and values in Islamic law which will affect the condition of the community or group. This will be a continuing disturbance to the balance in society. And conditions like this will become tensions between people who do not have direction in dealing with the problem. If this imbalance can be handled properly, then the condition is called an adjustment, but if the condition happens to the contrary, then something is not appropriate.

At present the condition of society is faced with two choices, namely adhering to the norms of religious law while subduing the realities of life, and the need for a new law before the authority of religious law, or abandoning religious law because it is no longer functional to accommodate legal needs and a sense of justice. Public. The more sophisticated the technology of the Islamic world, the easier it is to touch and interact with westernization through colonialism that was carried out by western culture to eastern culture, especially the Islamic world. This contact between eastern and western civilizations has an impact on social changes which will then give birth to several new problems for the Muslim community. These changes will give rise to a new culture that is explicitly absent from existing Islamic law. 
Social change is a sure thing to happen in a society. It should be noted that the changes that occur must affect the social life of a community group. With regard to this change, sociologists give several points of emphasis that are not the same as one another. However, whatever the emphasis is given by the sociologists, they have agreed that social change has the character of influencing and changing the order of the social system which has been assumed to be something standard.

One aspect of Islamic law is that it is considered a traditional religious heritage. But in the social field it is no longer seen as fulfilling the needs of the times. Therefore, reform of Islamic law is a necessity. The social changes that Muslims have faced in the modern period have given rise to a number of serious problems with regard to Islamic law. In connection with social change, Islamic law functions as a safety fence or fortress for society. As for the function; first, as social control, and second, as new values in the process of social change. If the first function is as social control as well as social engineering towards the existence of a new culture of mixing customs. Meanwhile, the second is placed as a justification for demands for social change, both in culture and as well as in politics.

Furthermore, Ibn Qayyim al-Jauziah has formulated four social factors that cause legal changes, namely; 1). The situation of the times, 2). Situation of the place, 3) Because of circumstances and desires, and 4). Customs or traditions. These four factors were formulated by Ibn Qayyim al-Jauziah in his figh principles, namely; taghayyur al-fatwa bi taghayyur alzaman wa al-makan wa al-ahwal wa al-'adah (changes in fatwas due to changing times, places, circumstances / intentions and customs), (Rosyadi, 2014).

A case whose legal status is clear and expressly stated explicitly and in detail in the Koran and al-Hadith, will not cause pros and cons among Muslims. Islamic law is a rule of Allah in which it must contain goodness, convenience and benefit. With this flow of social change, the Ulama are required to help issue fatwas in answering these problems to anticipate matters that are complex problems that arise. Thus the formulation of Islamic law aims to answer the needs of the times based on maqasid al-syari'ah and also maslahah Mursalah.

From the above description, it can be understood that the orientation of Islamic law is the benefit of human life as a whole. Islamic law can be a guide and provide solutions to problems or problems that arise in accordance with existing changes that occur in social society, both in the form of legal stipulations, or in the form of a regulation to organize human life itself. A state that applies Islamic law can clearly regulate behavior, position, structures and institutions in society. Islamic law can change society in a non-Islamic state if Islamic law is accommodated and made into positive law.

For example in the State of Indonesia, there is Islamic law which is accommodated into national laws such as in Law No.1 of 1974 concerning marriage. Before the birth of Law No.1 of 1974, the community easily divorced their wife, not through ligitation or nonligitation. But after the enactment of Law No.1 of 1974, then divorce is not considered to fall except through litigation or through a court, meaning that divorce can occur in court proceedings.

Even wives can sue for divorce from their husbands if the husbands do not fulfill or neglect their responsibilities as husbands, then the Marriage Law stipulates that wives can apply for divorce for their husbands to court. Whereas in Islamic law the wife's deed is called khuluk, namely giving the wife the right to ask for a divorce from her husband. To strengthen the role or position of the Marriage Law, the Compilation of Islamic Law (KHI) was born as a 
law that regulates the social life of the Muslim community including marriage cases (Samsudin, 2018).

Another issue related to Islamic law in the contemporary era is the era of globalization, where at this time people are so easy to communicate and transport, so that distance is no longer meaningful, besides that it is easy to access information, so it can be said that there are many advances in science and technology. However, this globalization has caused major changes in all aspects of life (Lubis, 2017).

There are many tools of science that can support the discovery and formulation of law to be applicable, such as the Science of Interpretation, Science of Hadith, Date, and Arabic Grammar. And no less important is social science. It is hoped that the convergence approach between ushul fiqh and other sciences will reduce the formalism of Islamic law (Azhari, 2016). In this context, the meaning of Islamic law does not have to be seen from a value perspective alone, but it is necessary to look for the organic and structural linkages in social life. Herein lies the importance of the phenomenon of the transformation of Islamic legal thought, not only seen as a religious phenomenon.

The transformation of Islamic legal thought is a creative struggle between Islam and social society, between Islamic values and the structural reality of society. Therefore, in Islamic law, social, cultural and geographic changes are important variables that influence legal changes. In a rule according to the jurists, it cannot be denied that the change in law due to the changing times is more specifically Ibn Qayyim al-Jauziah, said that the social factor is formulated in four ways, namely: 1). The situation of the times, 2). Sitei, 3) Because of circumstances and desires, and 4). Customs or traditions of these social factors.

According to Ibn Qayyim al-Jauziah fiqh in a fiqh principle Changing the fatwa due to changes in time, place, state / intention and customs. With the issues of changing Islamic law in the midst of social change, it can be concluded that Islamic law can affect social changes that exist in society. One thing that is important is to apply Islamic law in the midst of current conditions of social change in society paying more attention to the basic principles of goals that have been set in Islam. Thus with social change does not mean leaving the texts of the Alqur'an and Hadith and still relying on texts of the Al-qur'an and Hadith.

\section{Conclusion}

From the above discussion, it can be concluded that the relationship between Islamic law and social change is reciprocal. Which Islamic law can affect social change, and vice versa social change. The existence of legal changes due to social changes shows that Islamic law is dynamic and able to adapt to current conditions. The birth of fatwas from various schools of thought, even if there are changes are very important if people continue to pay attention to the basic principles of goals that have been set in Islamic law and the existence of social change does not mean leaving the texts of the Qur'an and Hadith. 


\section{References}

Abdulsyani. (2007). Sosiologi Skematika, Teori, dan Terapan. Jakarta: Bumi Aksara

Adi, R. (2012). Sosiologi hukum: kajian hukum secara sosiologis. Yayasan Pustaka Obor Indonesia.

Adibah, I. Z. (2017). Pendekatan Sosiologis Dalam Studi Islam. INSPIRASI: Jurnal Kajian dan Penelitian Pendidikan Islam, 1(1), 1-20.

Alfin, A., \& Busyro, B. (2017). Nikah Siri dalam Tinjauan Hukum Teoritis dan Sosiologi Hukum Islam Indonesia. Al-Manahij: Jurnal Kajian Hukum Islam, 11(1), 61-78.

Arikunto, S. (2010). Metode peneltian. Jakarta: Rineka Cipta.

Ash-Shiddiqey, T. M. H. (1990). Falsafat Hukum Islam (Cet. IV). Jakarta: Bulan Bintan

Azhari, F. (2016). Dinamika Perubahan Sosial dan Hukum Islam. Al Tahrir, 16(1), 197-221.

Azhary, M. T. (1987). Negara Hukum; Suatu Study tentang Prinsip-Prinsipnya Dilihat dari Segi Hukum Islam dan Implementasinya pada Periode Negara Madinah dan Masa Kini. Jakarta: Bulan Bintang.

Djazuli.(2005). Ilmu Fiqh Penggalian, Perkembangan dan Penerapan Hukum Islam. Jakrta: Kencana Prenada Media Grouf

Hamdi, I. (2018). Perluasan Makna Harta Bersama Perspektif Sosiologi Hukum Islam. JURIS (Jurnal Ilmiah Syariah), 17(1), 63-83.

Helmi, et al. (2019). Implementation Place of 'Uqubat Canings in Fiqh Perspective (Analysis of Aceh Governor Regulation Number 5 of 2018). Budapest International Research and Critics Institute-Journal (BIRCI-Journal). P. 65-73

Hilal, H. (2003). Mu’jam Mushthalah al-Ushul. Beirut: Dar al-Jil http://dx.doi.org/10.31958/juris.v18i1.1397

Lubis, H. R. (2017). Sosiologi Agama: Memahami Perkembangan Agama dalam Interaksi Islam. Kencana.

MacDonald, D. B. (1903). Development of Muslim Theology Jurisprudence and Constitutional Theory. New York: Charies Scribner's Sons

Munawarsyah, et al. (2018). Juridical Analysis of the Amount of Diyat Toward Armed Conflict Victims in Aceh. Budapest International Research and Critics Institute-Journal (BIRCI-Journal). P. 104-113

Muslim, M. I., \& Perdhana, M. S. (2017). Glass ceiling: sebuah studi literatur. Jurnal Bisnis Strategi, 26(1), 28-38.

Ridla, M. R. (2014). Sosiologi Hukum Islam (Analisis terhadap Pemikiran M. Atho'Mudzhar). Al-Ihkam: Jurnal Hukum dan Pranata Sosial, 7(2), 293-304.

Robert H. Laurer. (2003). Perspektive on Social Change, Terj. Alimandan SU. Jakarta: Rineka Cipta

Rokhmad, A. (2017). Paradigma Hukum Islam dalam Penyelesaian Sengketa. International Journal Ihya"Ulum al-Din, 18(1), 49-64.

Rosyadi, Imron. "Dialektika Hukum Islam Dan Perubahan Sosial Di Indonesia: Telaah FatwaFatwa Tarjih Muhammadiyah." Tajdida: Jurnal Pemikiran dan Gerakan Muhammadiyah 12, no. 2

Soekanto, S. (2007)). Teori Sosiologi Tentang Perubahan Sosial. Jakarta: Ghalia.

Syamsuddin. Muh $\}$ ammad Mahdi. al-Ijtiha $>$ d wa al-tajdi $>$ d fi al-Fiqhi $>$ al-Isla $>$ mi $>$. Beiru $>$ t: al-Dauliyah al-Muassasah, tt.

Ulwan, Abdullah Nashih.(1992). Syari'at Islam yang Abadi. terj. Daud Rasyid, Bandung: Usamah Press

Wagianto, R. (2017). Tradisi Kawin Colong pada Masyarakat Osing Banyuwangi Perspektif Sosiologi Hukum Islam. Al-Ahwal: Jurnal Hukum Keluarga Islam, 10(1), 61-84.

Wello, Abd. Malik.(2010) “Karakteristik dan Kedudukan Hukum Islam”,Al-Risalah 
Zayyadi, A. (2020). Dinamika Modernisasi Hukum Islam: Tinjauan Historis dalam Pembacaan Mazhab Sociological Jurisprudence. Al-Manahij: Jurnal Kajian Hukum Islam, 14(1), 99-112.

Zuhri, S. (2014). Menempatkan nilai-nilai fikih Islam dalam proses modernisasi dan perubahan sosial studi tentang teori al-Tufi mazhab Hanbali. Ijtihad: Jurnal Wacana Hukum Islam dan Kemanusiaan, 14(2), 167-187. 